\title{
The Influence of Foot Massage on Blood Pressure and Anxiety in Hypertensive Patients
}

Nyayu Nina Putri Calisanie* and Sabrina Preannisa

Nursing Science Program, STIKep PPNI Jawa Barat, Indonesia

\section{ORCID}

Nyayu Nina Putri Calisanie: https://orcid.org/0000-0002-3425-4258

Abstract. Hypertension is one of the most common conditions in the world, and if it is not treated promptly, it can create not only physical but also psychological issues. Anxiety is a psychological issue that can exacerbate hypertension symptoms. In people with hypertension, foot massage reflexology is a non-pharmacological therapy. The purpose of this study was to see if foot massage reflexology may help patients with hypertension lower their blood pressure and anxiety. The research design used was a quasi-experimental pretest-posttest design with a control group. The sample consisted of 56 respondents, who were separated into two groups, with 28 respondents in the intervention group and 28 respondents in the control group. The HARS questionnaire was used to collect the data on anxiety levels, and a digital sphygmomanometer was used to assess blood pressure. The results of this study indicated that there was a decrease in systolic blood pressure of $24.54 \mathrm{mmHg}$ and diastolic blood pressure of $9.75 \mathrm{mmHg}$, and a decrease in the anxiety score of 8.94 in the intervention group. The results of the ANCOVA statistical test suggested that there was a significant impact. This study concludes that giving foot massage therapy can significantly reduce systolic blood pressure, diastolic blood pressure and anxiety.

Keywords: anxiety, foot massage, hypertension

\section{Introduction}

High blood pressure often known as hypertension, is a condition in which the force of squeezing blood against the walls of the cavity where the blood is held rises [13]. Hypertension is a condition when systolic blood pressure is more than $140 \mathrm{mmHg}$ and diastolic blood pressure is more than $90 \mathrm{mmHg}$ on 2 measurements with an interval of 5 minutes in a state of enough rest/quiet [1].

Based on data in World Health Organization in 2017, Hypertension is thought to be responsible for 35.6 million fatalities annually, the majority of which are caused by heart disease and stroke. Hypertension also known as "The Silent Killer of Death". Hypertension affects around 1.13 billion individuals worldwide, which means that 1 in 
Hypertension, if left untreated, can lead to medical complications such as chronic renal disease, coronary heart disease and stroke. However, it can also affect to psychological conditions such as anxiety [2]. Anxiety is an emotional reaction to subjective individual judgments influenced by the subconscious and the cause isn't known specifically [3]. Anxiety disorders that last a long time cause sleep disruptions, digestive problems, a weakened immune system, excretory system problems, and heart rhythm problems, all of which can contribute to hypertension [4].

If blood pressure and anxiety are not controlled, the condition of hypertension and anxiety will worsen [5]. Hypertension can be controlled in 2 methods, pharmacological and non-pharmacological methods. The use of medications to assist reduce and regulate blood pressure is known as pharmacological therapy. Pharmacological treatment, on the other hand, has adverse effects that can exacerbate the disease. This is due to the fact that each person's reaction to a medicine is different [6]. Complementary therapy can be used for a variety of non-pharmacological treatments. Complementary therapy can be one of the options for reducing the side effects of pharmaceutical treatment. Non-pharmacological treatments for hypertensive patients include stress reduction techniques, alcohol and smoke restrictions, exercise, relaxation and acupressure [5]. Relaxation therapy, such as foot massage reflexology, is one of the supplementary therapies that can be used [7].

Foot massage reflexology is a method of massaging certain points on the feet, the benefits for health are unquestionable. Since the days of the ancestors, massage is believed to be able to overcome complaints such as muscle disorders, blood pressure disorders, and psychological disorders. Massage in the foot area will send a signal that stimulates the release of hormones such as endorphins, causing a relaxing effect so that blood pressure and anxiety will decrease. The body will produce many hormones such as serotonin, histamine, and bradykinin if the massage is done at a point. These hormones stimulate capillary and arteriolar dilation, which increases the circulation of small blood vessels and has a relaxing impact on stiff muscles, As a result blood pressure will decrease steadily [8].

\section{Methods}

This study is a quantitative study using a Quasi Experimental Pre-Posttest Design with Control Groups, which was carried out in the work area of the UPT Puskesmas Pasir Kaliki Bandung City on April 20, 2021 to May 2, 2021. 
Sample size prediction is calculated with G-Power Software 3.1.9.7 using F-Test, ANCOVA : Fixed effect, main effects and interaction with assumption two-tails, score $\alpha=0.05$, effect size $=0.6$, power level $=0.8$. So that a sample of this study is 58 hypertensive patients who visited UPT Puskesmas Pasir Kaliki in Bandung City and were chosen using a purposive sampling technique. The inclusion criteria were that the patients were 35-65 years old, not pregnant, and had no skin damage on their lower extremities, such as burns, gangrene wounds or tumors.

A digital sphygmomanometer was used to take blood pressure readings, which had been calibrated with wearable findings. Meanwhile, anxiety is measured using the HARS (Hamilton Anxiety Rating Scale) questionnaire, which has been tested for validity and reliability with valid and reliable results. Data analysis in this study was carried out using IBM SPSS statistical software version 23 with Paired T Test and ANCOVA statistical tests

\section{Result}

\subsection{Characteristics of respondents}

Based on Table 1, As can be seen, the majority of respondents (64.3\%) are women with an average age of $55.46(S D=5.27)$ with the majority of the last education (26.8\%) being Vocational School and working as housewives (50.0\%). Most respondents (42.9\%) had been diagnosed with hypertension for 2 years. All respondents (100\%) took antihypertensive drugs.

The results of the Independent T Test ( $p$ value $>0.05$ ) and Chi-Square ( $p$ value $<0.05)$ indicate that there wasn't significant difference between the control group and the intervention group in the metter of age, last education, duration of hypertension and taking antihypertensive drugs. And there are significant differences in gender.

\subsection{Lowering Blood Pressure and Anxiety Before and After the Foot Massage Intervention}

The Paired T Test was carried out to prove the hypothesis that had been made previously, namely the effect of foot massage on reducing blood pressure and anxiety in hypertension sufferers in the intervention group and the control group because it tested two paired samples on the same subject.

Based on the table above, the average systolic blood pressure in the intervention group decreased from $165.18 \mathrm{mmHg}(S D=13.004)$ to $140.64 \mathrm{mmHg}(S D=12.535)$ with a $p$ 
TABLE 1: Characteristics of Respondents Based on Gender, Age, Last Education, Occupation, Length of Suffering from Hypertension and Consuming Anti Hypertension Drugs ( $n: 56$ )

\begin{tabular}{|c|c|c|c|c|}
\hline Variable & $\begin{array}{l}\text { Total } \quad n=56 \\
\text { (\%) }\end{array}$ & $\begin{array}{l}\text { Intervention } \\
n=28 \text { (\%) }\end{array}$ & $\begin{array}{l}\text { Control } n=28 \\
\text { (\%) }\end{array}$ & p-Value \\
\hline Gender & & & & 0.093 \\
\hline Male & $20(35.7)$ & $11(19.6)$ & $9(16.1)$ & \\
\hline Female & $36(64.3)$ & $17(30.4)$ & 19 (33.9) & \\
\hline Age (Mean $\pm S D)$ & $55.46 \pm 5.27$ & $53.57 \pm 5.37$ & $57.36 \pm 4.47$ & 0.200 \\
\hline Education & & & & 0.049 \\
\hline Elementary & $16(28.6)$ & $5(8.9)$ & 11 (19.6) & \\
\hline Junior High & $10(17.9)$ & $6(10.7)$ & $4(7.1)$ & \\
\hline Senior High & 24 (42.9) & $15(26.8)$ & 9 (16.1) & \\
\hline Bachelor & $6(10.7)$ & $2(3.6)$ & $4(7.1)$ & \\
\hline Occupation & & & & 0.008 \\
\hline Employee & 5 (8.9) & $4(7.1)$ & $1(1.8)$ & \\
\hline Government & 8 (14.3) & $4(7.1)$ & $4(7.1)$ & \\
\hline Entrepreneur & $12(26.8)$ & 7 (12.5) & $8(14.3)$ & \\
\hline House Wife & $28(50.0)$ & $13(23.2)$ & $15(26.8)$ & \\
\hline $\begin{array}{l}\text { Hypertensive } \\
\text { Time Suffering } \\
\text { (Mean } \pm \text { SD) }\end{array}$ & $3.20 \pm 2.77$ & $4.25 \pm 3.58$ & $3.13 \pm 3.08$ & 0.471 \\
\hline \multicolumn{3}{|c|}{ Anti-Hypertensive Drug Consumption } & & 0.000 \\
\hline Yes & $56(100.0)$ & $28(50.0)$ & $28(50.0)$ & \\
\hline No & $0(00.0)$ & $0(00.0)$ & $0(00.0)$ & \\
\hline
\end{tabular}

value of 0.000 ( $p$ value $<0.05$ ). Then the average diastolic blood pressure decreased from $91.93 \mathrm{mmHg}(\mathrm{SD}=9.970)$ to $82.18 \mathrm{mmHg}(\mathrm{SD}=7.124)$ with a $\mathrm{p}$ value of 0.000 ( $\mathrm{p}$ value $<0.05)$ and then the average anxiety score also decreased from $33.57(\mathrm{SD}=4.574)$ to 24.61 ( $S D=3.119$ ) with a $p$ value of 0.000 ( $p$ value $<0.05$ ). Based on the results of the Paired T Test statistical test, it was known that the $P$ Value $<(\alpha=0.05)$ there was a significant decrease between the average systolic pressure, diastolic blood pressure and anxiety score after being given foot massage intervention. The data analysis can conclude that there are significant differences in blood pressure and anxiety before and after being given foot massage intervention in the intervention group.

In addition, in the control group the average systolic blood pressure decreased from $168.64 \mathrm{mmHg}(\mathrm{SD}=12.664)$ to 165.96 ( $S D=12.802)$ with a $p$ value of 0.001 ( $p$ value $<0.05$ ), while the average diastolic blood pressure decreased from $93.32 \mathrm{mmHg}(\mathrm{SD}=9,460)$ to $89.57 \mathrm{mmHg}(S D=6,298)$ with a $p$ value of 0.010 ( $p$ value $<0.05)$. Then for the average anxiety score decreased from $31.18(S D=5,690)$ to $30.43(S D=5,322)$ with a $p$ value of 0.000 ( $p$ value $<0.05$ ). The ANCOVA statistical test was carried out to determine the 
TABLE 2: Blood pressure and anxiety levels were compared before and after the foot massage intervention $(n=56)$

\begin{tabular}{|c|c|c|c|c|c|}
\hline \multirow[t]{2}{*}{ Variable } & \multicolumn{2}{|c|}{$\operatorname{Mean}_{ \pm} \mathrm{SD}$} & \multirow{2}{*}{$\begin{array}{l}\text { Mean } \\
\text { Difference }\end{array}$} & \multirow[t]{2}{*}{$\mathbf{t}$} & \multirow{2}{*}{$\begin{array}{l}\text { p- } \\
\text { Value }\end{array}$} \\
\hline & Pre Test & Post Test & & & \\
\hline \multicolumn{6}{|l|}{ Systolic } \\
\hline Intervention & $165.18 \pm 13.004$ & $140.64 \pm 12.535$ & 25.54 & -19.438 & 0.000 \\
\hline Control & $168.64 \pm 12.664$ & $165.96 \pm 12.802$ & 2.68 & -3.543 & 0.001 \\
\hline \multicolumn{6}{|l|}{ Diastolic } \\
\hline Intervention & $91.93 \pm 9.970$ & $82.18 \pm 7.124$ & 9.75 & -7.266 & 0.000 \\
\hline Control & $93.32 \pm 9.460$ & $89.57 \pm 6.298$ & 3.78 & 2.760 & 0.010 \\
\hline \multicolumn{6}{|c|}{ Total Score Anxiety } \\
\hline Intervention & $33.57 \pm 4.574$ & $24.61 \pm 3.119$ & 8.96 & 18.528 & 0.000 \\
\hline Control & $31.18 \pm 5.690$ & $30.43 \pm 5.322$ & 0.75 & 4.104 & 0.000 \\
\hline \multicolumn{6}{|l|}{ Psychology } \\
\hline Intervention & $13.46 \pm 3.636$ & $9.89 \pm 2.499$ & 3.57 & 10.660 & 0.000 \\
\hline Control & $12.46 \pm 3.666$ & $12.25 \pm 3.503$ & 0.21 & 2.274 & 0.031 \\
\hline \multicolumn{6}{|l|}{ Somatic } \\
\hline Intervention & $20.11 \pm 3.035$ & $14.71 \pm 2.209$ & 5.40 & -14.493 & 0.000 \\
\hline Control & $18.71 \pm 2.774$ & $18.18 \pm 2.539$ & 0.53 & 4.920 & 0.000 \\
\hline
\end{tabular}

difference between giving foot massage to reducing blood pressure and anxiety in the intervention group and the control group before and after being given treatment.

Based on the results of the ANCOVA statistical test on systolic blood pressure, diastolic blood pressure and anxiety scores, the $P$ Value $<\alpha(\alpha=0.05)$, so it can be concluded that $\mathrm{H}_{0}$ was rejected and $\mathrm{H}_{a}$ was accepted. The data analysis shows that after receiving foot massage, the intervention and control groups have substantial variations in systolic blood pressure, diastolic blood pressure, and anxiety.

\section{Discussion}

\subsection{Characteristics of respondents}

The total number of persons that took part in this study was 56 , with 36 women and 20 men. Women are more vulnerable to stress because their brain cells are more sensitive to stress hormones, which can cause hypertension by activating the sympathetic nervous system, resulting in an intermittent (uncertain) rise in blood pressure. When someone is stressed, adrenaline hormone rises, causing an increase in blood pressure due to artery constriction (vasoconstriction) and a rise in heart rate [9]. 
TABLE 3: Comparison of Systolic Blood Pressure Decreases in the Intervention and Control Groups before and after receiving Foot Massage $(n=56)$

\begin{tabular}{|c|c|c|c|c|c|}
\hline Source & $\begin{array}{l}\text { Type III Sum } \\
\text { of Squares }\end{array}$ & Df & $\begin{array}{l}\text { Mean } \\
\text { Square }\end{array}$ & $\mathbf{F}$ & Sig. \\
\hline $\begin{array}{ll}\text { Sistolik } & \text { Blood } \\
\text { Pressure } & \end{array}$ & & & & & \\
\hline Corrected Model & 7747.310 & 2 & 3738.655 & 125.949 & .000 \\
\hline Intercept & 250.141 & 1 & 250.141 & 8.427 & .005 \\
\hline Group & 2693.176 & 1 & 2693.176 & 90.729 & .000 \\
\hline Pre Test Systolic & 7309.292 & 1 & 7309.292 & 246.238 & .000 \\
\hline Error & 1573.244 & 53 & 29.684 & & \\
\hline Total & 1569165 & 56 & & & \\
\hline Corected Total & 9050.554 & 55 & & & \\
\hline $\begin{array}{l}\text { Diastolik Blood } \\
\text { Pressure }\end{array}$ & & & & & \\
\hline Corrected Model & 2371.599 & 2 & 1185.799 & 22.808 & .000 \\
\hline Intercept & 23.579 & 1 & 23.579 & .454 & .504 \\
\hline Group & 365.065 & 1 & 365.065 & 7.022 & .011 \\
\hline Pre Test Systolic & 2344.438 & 1 & 2344.438 & 45.093 & .000 \\
\hline Error & 2755.526 & 53 & 51.991 & & \\
\hline Total & 485573 & 56 & & & \\
\hline Corected Total & 5127.125 & 55 & & & \\
\hline \multicolumn{6}{|l|}{ Anxiety Score } \\
\hline Corrected Model & 1327.560 & 2 & 663.780 & 183.647 & .000 \\
\hline Intercept & 5.599 & 1 & 5.599 & 1.549 & .219 \\
\hline Group & 742.864 & 1 & 742.864 & 205.527 & .000 \\
\hline Pre Test Systolic & 1247.399 & 1 & 1247.399 & 345.116 & .000 \\
\hline Error & 191.565 & 53 & 3.614 & & \\
\hline Total & 60215 & 56 & & & \\
\hline Corected Total & 1519.125 & 55 & & & \\
\hline
\end{tabular}

In addition, women who enter menopause tend to have higher blood pressure because the level of the hormone estrogen, which functions to protect women from cardiovascular disease, is decreasing [7]. The outcome of this study are supported by research [6], from 30 respondents, 25 respondents were female. This is because women are more prone to experiencing hormonal imbalances due to menopause and stress.

The respondents in this study were 55.46 years old on average (SD =5.27). Increasing age causes hormonal changes and changes in the vascular, the elasticity of the arteries decreases and becomes stiff [6]. This situation can cause the arteries to not expand when the heart pumps blood so that the blood flowing isn't smooth, cause increase in blood pressure [7]. These findings are consist with research conduct by [10] that the respondents average age is $\mathbf{5 5 . 7 7}$ years because as age goes on, the elasticity of 
blood vessels will decrease so that it can cause blood flow not smooth as a result blood pressure increases.

In this study, 24 of the 56 participants had completed high school. The ability to manage and process information before it becomes harmful to one's health is influenced by one's educational degree [6]. This is in line with the findings of [2], who found that 17 out of 40 respondents have a vocational education, indicating that a person's attempts to preserve his health are influenced by his educational level.

In this survey, a total of 28 respondents worked as housewives. Physically active people have a greater heart rate, which means the heart muscle has to work harder every time it pumps blood [6]. This is in line with [6] research, which found that 19 out of 30 respondents experience greater stress as a result of excessive activity at home.

The results of this study showed that the average respondent has been diagnosed with hypertension for 3.20 years $(S D=2.77)$ and has a $100 \%$ medication adherence rate. However, over time a person tends to disobey because he feels tired of taking medication. The saturation factor of hypertensive patients undergoing treatment and the cure rate achieved isn't as expected can also be a factor in non-compliance [11]. This is in line with research by [11], many of the 21 respondents who had been diagnosed with hypertension for less than 5 years had a high degree of drug adherence because they still cared about their health.

\subsection{The Influence Foot Massage}

According to the findings of this study, hypertension patients who given foot massage therapy 3 times in a row for 30-45 minutes in 3 days indicate significant changes in systolic blood pressure, diastolic blood pressure and anxiety. This is evidenced by the decrease in mean systolic blood pressure from the intervention group from $165.18 \mathrm{mmHg}$ to $140.64 \mathrm{mmHg}$ (Decreased by $24.54 \mathrm{mmHg}$ ) and diastolic blood pressure decreased from $91.93 \mathrm{mmHg}$ to $82.18 \mathrm{mmHg}$ (Decreased by $9.75 \mathrm{mmHg}$ ). In addition, the average anxiety score in the intervention group decreased from 33.57 to 24.61 (decreased by 8.97).

Foot massage is a type of passive exercise that can have a soothing effect by reducing sympathetic nervous system activity, lowering blood pressure and increasing blood circulation in the body. Blood arteries dilate reflexively when nerve receptors are stimulated [6].

These findings are consist with research conduct by [12], in 57 people ( 5 men and 52 women) who received aroma foot massage intervention, which significantly reduced 
the average SBP $(p$ value $=0.02$ ) before $114.1 \mathrm{mmHg}$ and after the intervention 110.0 $\mathrm{mmHg}$, DBP before intervention $70.5 \mathrm{mmHg}$ and after intervention $68.8 \mathrm{mmHg}$ ( $p$ value $=0.006$ ), and There was a significant reduction in anxiety scores from 40 to 35 ( $p$ value $=0.003)$.

Massage induces the production of the hormone histamine, which aids in blood vessel dilatation [10]. As a result, blood flow, nutrient circulation, and oxygen distribution to body cells improve. Smooth blood circulation provides a calming and refreshing effect on all body members, the result in a balanced state for the body [7]. In addition, the impact of foot massage therapy is able to manipulate the body system, causing a relaxed condition, balancing blood flow throughout the body and reducing anxiety [4].

Based on the results of this study, the control group also decreased, this is evidenced by the results systolic blood pressure reduce from $168.64 \mathrm{mmHg}$ to $165.96 \mathrm{mmHg}$ (Decreased $2.68 \mathrm{mmHg}$ ) and in diastolic it decreased from $93.92 \mathrm{mmHg}$ to $89.57 \mathrm{mmHg}$ (Decreased $4.35 \mathrm{mmHg}$ ). Then, the decrease in anxiety scores in the control group from 31.18 to 30.43 (only decreased by 0.75 ). Because the control group's respondents had been diagnosed with hypertension for an average of 5 years, they had a high level of drug adherence. The opinion of World Health Organization, Antihypertensive medications aid in the reduction of hypertension-related problems by lowering and stabilizing blood pressure.

Based on research that has been done, there are differences in systolic blood pressure, diastolic blood pressure and anxiety scores after being given foot massage therapy in the intervention and control groups. This is evidenced by the $p$-Value of the ANCOVA test in the intervention group and control group is 0.000 ( $p$ value $<0.05$ ) on systolic blood pressure, 0.003 ( $p$ value $<0.05$ ) on diastolic blood pressure and 0.000 ( $p$ value $<0.05$ ) in anxiety score.

The data analysis states that there are significant differences in blood pressure and anxiety before and after being given foot massage intervention in the intervention group and the control group. This study concluded that giving foot massage therapy can significantly reduce systolic blood pressure, diastolic blood pressure and anxiety.

Therapy massage performed on a regular basis can lower levels of the stress hormone cortisol, as well as sources of depression and anxiety, allowing blood pressure to stable and physiological functions to improve [10]. According to [12], one of the best ways to reduce blood pressure and anxiety is with foot massage therapy.

The respondent felt calmer, his body felt lighter, and his headache was lessened after receiving this foot massage therapy. As a result, foot massage therapy may be advised as a supplemental therapy for blood pressure and anxiety prevention. 


\section{Conclusion}

In this study, it was found that most of the respondents (64.3\%) were female with 55.46 years old on average $(S D=5.27)$ with the majority of the last education (26.8\%) being Vocational School and working as housewives (50.0\%). The average respondent has been diagnosed with hypertension for 3.20 years $(S D=2.77)$. All respondents $(100 \%)$ took anti-hypertensive drugs.

According the results of statistical tests using the Paired T Test in the control group and the intervention group, the results obtained with $p$-Value values of 0.000 each $(p$-Value $<(\alpha=0.05))$. This means that an effect of foot massage on systolic, diastolic blood pressure and anxiety in patients with hypertension in each group.

The results of the ANCOVA statistical test on systolic blood pressure, diastolic blood pressure and anxiety scores, $P$ Value $<(\alpha=0.05)$. The results of this study showed that the first hypothesis, that is $\mathrm{H}_{0}$ is rejected and $\mathrm{H}_{a}$ is accepted, so it can be stated that there are significant differences in systolic blood pressure, diastolic blood pressure and anxiety in the intervention and control groups after being given foot massage intervention.

\section{Suggest}

\subsection{For the Development of Nursing Science}

This study can serve as a new reference for nursing science, particularly in the management of foot massage to controlled blood pressure and anxiety in hypertensive patients, as well as scientific evidence for controlled of foot massage on lowering blood pressure and anxiety in hypertensive patients.

\subsection{For Further Research}

It is intended that this study may be used as evidence-based research and as a title for future studies on the other benefits of foot massage therapy.REFERENCES

\section{References}

[1] Yulanda G, Lisiswanti R. Penatalaksanaan hipertensi primer. Majority. 2017;6(1):2533. 
[2] Pramana KD, Okatiranti, Ningrum T. Hubungan tingkat kecemasan dengan kejadian hipertensi di panti sosial tresna werdha senjaeawi bandung. Jurnal Ilmu Keperawatan. 2016;4(5):1174-1181.

[3] Johnson HM. Anxiety and hypertension: Is there a link? A literature review of the comorbidity relationship between anxiety and hypertension. Current Hypertension Reports. 2019;21(9):22-26.

[4] Amaludin MM, Hamzah H, Muhsinin M. Pengaruh terapi foot message terhadap kecemasan pasien gagal ginjal kronik yang menjalani hemodialisa di rsud ulin banjarmasin. Jurnal Keperawatan Suaka Insan ( Jksi). 2020;5(1):36-51.

[5] Syafi'i A. Pengaruh terapi masase, masase dengan yoga, dan masase dengan meditasi terhadap penurunan tekanan darah dan tingkat kecemasan pada penderita hipertensi. Massage for Sport Therapy and Injury. 2019;1(1):18-29.

[6] Arianto, A., Prastiwi, S., \& Sutriningsih, A. Pengaruh terapi pijat refeleksi telapak kaki terhadap perubahan tekanan darah pada penderita hipertensi. Nursing News. 2018;3(1):584-594.

[7] Arianto A, Prastiwi S, Sutriningsih A. Pengaruh terapi pijat refleksi telapak kaki terhadap perubahan tekanan darah pada penderita hipertensi. Junal IImiah Keperawatan. 2018;3:584-594.

[8] Ardiansyah, Huriah, T. Metode massage terhadap tekanan darah pada penderita hipertensi: A literature review. Jurnal Penelitian Keperawatan. 2019;5(1).

[9] Hasri $H$. Hubungan antara stres dengan hipertensi pada pasien rawat jalan di puskesmas rapak mahang kabupaten kutai kartanegara provinsi kalimantan timur. (Doctoral dissertation, Universitas Muhammadiyah Surakarta). 2015.

[10] Widyaningrum T. Pengaruh Swedish massage terhadap penurunan tekanan darah pada pasien HT di RS An - Nisa tangerang tahun 2020. 2020.

[11] Balqis S. Hubungan lama sakit dengan kepatuhan minum obat pada pasien hipertensi di dusun ambarketawang gamping selatan Yogyakarta. 2018.

[12] Eguchi E, Funakubo N, Tomooka K, Ohira T, Ogino K, Tanigawa T. The effects of aroma foot massage on blood pressure and anxiety in Japanese community-dwelling men and women: A crossover randomized controlled trial. PLoS ONE. 2016;11(3):1-13.

[13] Irianto K. Anatomi dan fisologi. Bandung: Alfabeta CV; 2017. 